\title{
REVITALIZING EARLY STAGES OF HEALTH AND SAFETY LEGISLATION AS A CHALLENGE AMONG MAJOR ECONOMIES
}

(CZikriyoev A., Tashkent Institute of Architecture and Civil Engineering, Tashkent,Uzbekistan,gishtimir@mail.ru

\section{ВОССТАНОВЛЕНИЕ РАННИХ ЭТАПОВ ЗАКОНОДАТЕЛЬСТВА ЗДРАВООХРАНЕНИЯ И БЕЗОПАСНОСТИ КАК ВЫЗОВ СРЕДИ ОСНОВНЫХ ЭКОНОМИК}

\section{(C)Зикриеев A. C., Ташкентский архитектурно-строительный институт, 2. Ташкент, Узбекистан, gishtimir@mail.ru}

Abstract. A dynamically developing modern society is characterized by a powerful scientific and technological breakthrough. The application of knowledge cannot only contribute to the evolution of society, but also threaten its safety. In the modern world due to the development of industrial technology danger grows faster than human resistance at work. The latter circumstance indicates the need to strengthen the preparation of citizens to safe behavior and their active civil security positions. Conditions of the new approach ensured the best work places based on the principle of Health and Safety towards regulation stages over the years among major economies. The main goal is to formulate safety regulations scientifically which study in solving the engineering problem, design-construction business, organizational or production process accidents. Challenges among major economies of 20 century were real implementations of theoretical approaches in health and safety in various methodologies.

Аннотация. Динамично развивающееся современное общество характеризуется мощным научно-техническим прорывом. Применение знаний может не только способствовать развитию общества, но и угрожать его безопасности. В современном мире благодаря развитию промышленных технологий опасность растет быстрее, чем сопротивление человека на работе. Последнее обстоятельство указывает на необходимость усиления подготовки граждан к безопасному поведению и их активных позиций в сфере гражданской безопасности. В изменившихся условиях подход к обеспечению наилучших условий труда, основанный на принципах охраны труда и техники безопасности, должен в течение многих лет уступать место новым законодательным этапам в основных экономиках. Основная цель состоит в том, чтобы научно сформулировать правила безопасности, которые изучают решение инженерных проблем, проектно-конструкторских работ, организационных или производственных аварий. Вызовами среди основных экономик 20 века были реализации теоретических подходов в области охраны труда и здоровья в различных методологиях.

Keywords: industrial development, health and safety, major economies, accident rate, legislation.

Ключевые слова: промышленное развитие, здравоохранение и безопасность, крупные экономики, уровень аварийности, законодательство. 


\section{Introduction}

The problem of ensuring human security is every society is an important issue for the state and its economic development stability. This has already led to scientific and technical progress a great deal of solution to the complex problems that created during production line. This is just an economically powerful, scientific and technical a state with intellectual potential among Former Soviet Union, United States and United Kingdom early reforms of safety regulations in the modern history. Other solution of safety issues from the community active involvement of its industrial sectors extension the higher civic consciousness, and in some social benefits of the future generations, to avoid personal safety requirements. Deeper analysis of these principles made scientifically organizing work stations in industry. After WWII diversification of industrial materials and rapidly changing in technological processes, mechanized level and automated, computerized, modernized potable systems were commonly used all these countries [1].

In th is, case high demand on labor protection demanded at construction industry for the several sectors. Improved working conditions and high safety at enterprises of all technical, organizational, legal, economic methods to ensure the effectiveness of the production line at that time. The legislation of Health and Safety includes social and legal goals the teethe of employee is a classic science, such as physics, chemistry, and technical approaches. Practical-labor hygiene, production with mathematics sanitation, labor psychology, ergonomics, engineering, industry aesthetics and other sciences were directions of the legislation objectives. The methodological basis of this work is the working conditions, technological process, disposal of hazardous substances and their use a scientific analysis of the dangers that may arise. These analyses hazardous in the production sector identify accidental situations, prevent and eliminate them developed time by time. All these issues all together were future development regulations taken into account nowadays.

But, insufficient the of relationship among many rules, codes and laws in safety, health, and protection at work have been applying by different departments by their own request. Our research provides Labor Protection, Work Activity Safety and Technical Safety Regulations by national legislations or scientific methodology are have to be studied as a complex system which ILO, US, Canada, EU, UK and Australia currently uses as Health and Safety Law. We have learned major safety regulations and gave our own methods for rising effectiveness the of construction industry by reducing accidents at work in Uzbekistan.

\section{Purpose}

Main goal of this paper work to is identify western fundamental approaches about needs Health and Safety Lathe in industry and compare with Russian methodology which directly matches with national legislation about safety at work. We would like to fa in relationship with three different approaches for providing safety which currently studying by Uzbek scholars and applying at various sectors of industry.

\section{Methods}

Based on the research question, this study was designed according to the stages presented in comparative analyses and secondary data collection. Data collected from various sources and some historical backgrounds of the appearance of the initial safety norms and rule the in-world economy.

\section{Discussion}

After the Industrial Revolution (20-60th of the XIX century), all sectors of the world economy developed rapidly. As a result, the health and safety of workers the in production and service sectors has become one of the priority issues of human working style. In these areas, which 
require high levels of attention, the Former Soviet Union, the United States and the United Kingdom have achieved a high level of socioeconomic efficiency by ensuring human health and safety even at that time. This study focuses on the introduction of the first health and safety regulatory or regulatory framework among the world's largest economies. In addition, effective reforms have been introduced to protect employees from any occupational hazards or accidents during the first competitive phase of the all industrial sectors of the world.

It has been following the initial standards for human health and safety the in industry the of US, UK, and Russian Federation. Outlines to come from the all new approaches and historically emerging working conditions in the industrial manufacturing process based on primarily technology and effective use of these production factors (https://clck.ru/FbvyZ).

IMPLEMENTATION OF RULES ON HUMAN HEALTH AND SAFETY ACROSS COUNTRIES

Table 1. (https://clck.ru/Fbvyh)

\begin{tabular}{llc}
\hline \multicolumn{1}{c}{ Country } & \multicolumn{1}{c}{ Name } & YearThe \\
\hline U.S. & Occupational Safety and Health Act & 1970 \\
UK & Health and Safety Act & 1974 \\
Canada & Occupational Safety and Health Act & 1978 \\
European Union & European Health and Safety Guidelines & 1987 \\
Australia & Occupational Health and Safety Act & 1984 \\
Malaysia & Occupational Health and Safety Act & 1994 \\
Russia & Health and Safety Rules in Work & 2001 \\
\hline
\end{tabular}

\section{United Kingdom}

For the first time in the history of industrial history, Britain was worried about the health of children working in cotton factories since the early years of the 19th century (1802) and Professional Practice Inspectorate was established on the basis of the 1833 Act. The Inspection initiated early childhood and youth workshops in the textile industry (chronic illness, direct health and deformations, and potentially high-risk activities). However, according to the factory inspectorate, another law adopted in 1844, which limits employment time for women in the textile industry, requires the protection of industrial vehicles (only in the textile industry, only women and children) (https://clck.ru/Fbvyt).

In 1840, the Royal Command (from where it came from) began to demand information about the working conditions of the mining industry workers, the dangerous environment they were working on and the statements of high accidents. The Commission raised the anger of the public in the 1842 Mines Act (what it meant). In the region, an inspection across all sectors of the industry (this is the first form of the current trade union) has resulted in many criminal cases being prevented and security measures have been taken. By 1850, safety inspectors began to conduct regular inspections at industrial sites to ensure human security in production [2].

According to the report of the United Nations Industrial Development Organization (UNIDO) for the safety of life of the construction industry in 2018, 600,000 employees fell into depression, 500,000 were diseased and $13.5 \mathrm{bn}$. US dollars were damaged. At the same time, the injuries sustained by 600,000 people, severe injuries of 71.1 employees and deaths of 144 employees resulted in $7.1 \mathrm{bn}$. Damage to the US dollar. As a result, 2017 loss of 30.7 million working days, of which 12,000 employees have lung diseases and 2595 workers have been subjected to various dusty and adverse conditions of lung disease. As a result of these indicators, construction companies' employees received 21 billion sums in total. In the US dollars, he has suffered material damage [3]. 


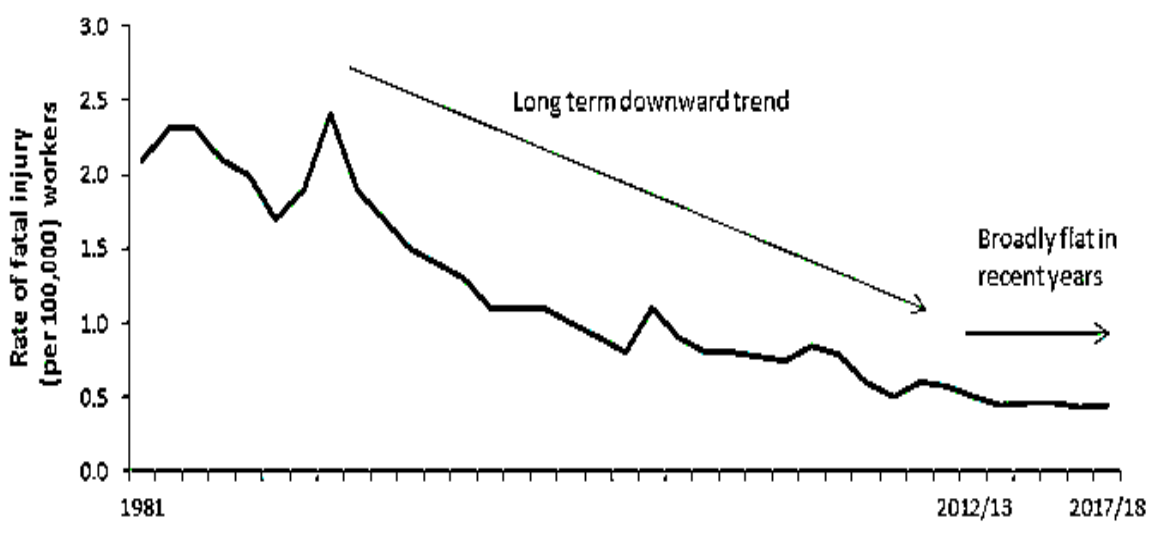

Figure 1. Breakdown of UK industry accident rate, 1981-2017 (Compared to 100,000 employees) (https://clck.ru/Fbvz5). Source: Image result for health and safety rate in the UK Health and Safety Statistics, banyardsolutions.co.uk.

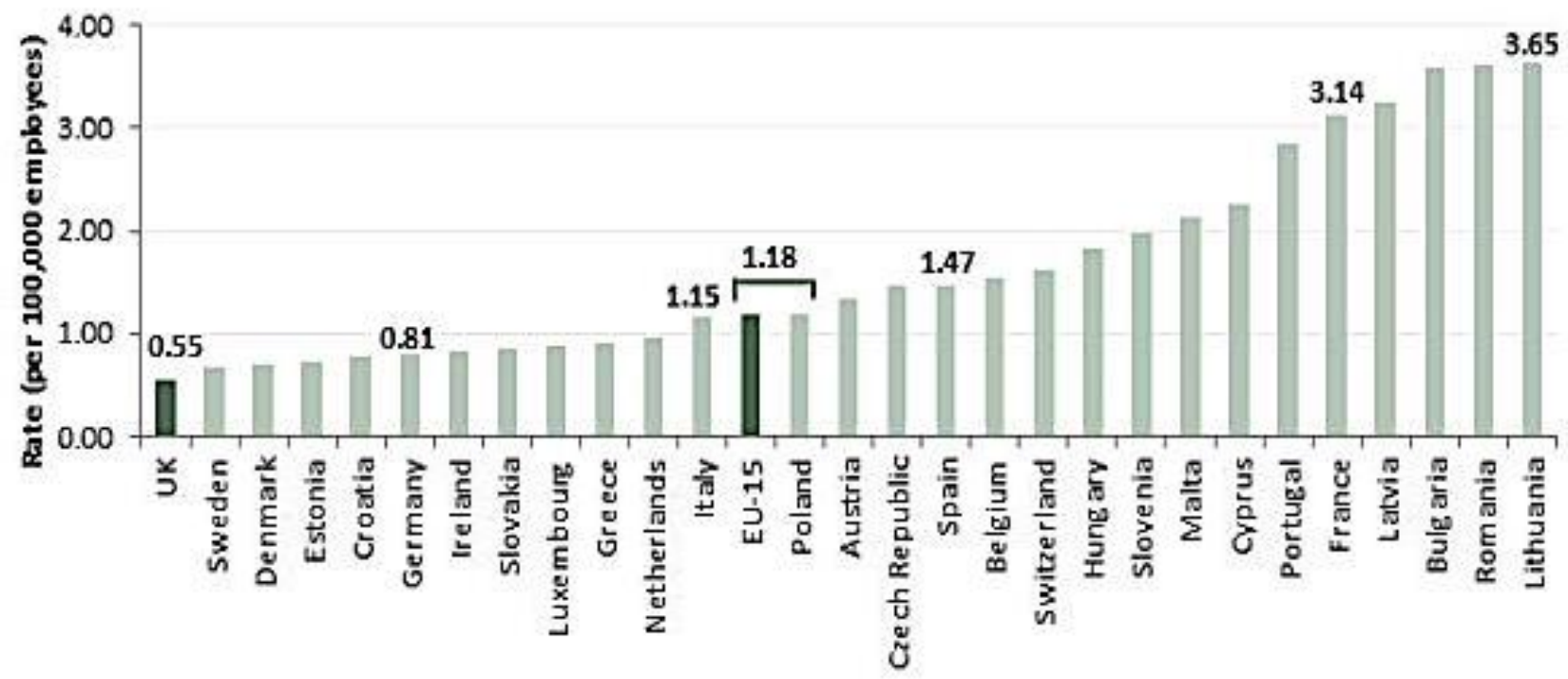

Figure 2. Accident rates of the fatal injuries at work in the world, 2016. Source: https://clck.ru/Fbvz5.

\section{Russian Federation (former the Soviet Union)}

The legitimate successor to the former Soviet Union has a long history of health and safety legislation in an independent Russian state. The first edition of Health and Safety Control, which began in 1719 with the Peter the Great. Russia's health and safety legislation has followed the same model as many Western European countries in whole. This type of legislation has been very successful for many today. Later, the Russian law was put forward as a basis for all stakeholders, including employers, employees, the government and the public - to meet the working conditions [4].

In the 20th century, the former Soviet Union was the country with the highest socioeconomic efficiency. One of the decisions taken by the Government during the Stalin era (which decision) aimed at reducing the number of events and occupational diseases in the industry. Nevertheless, the Regulation on Industrial Labor (1913) attempted to formulate the concept of 'labor protection' (from Stalin to the White Age) (There is no connection between the Statute and the Concept, and there is no concept at the tithe me of adoption of the Charter). Measures to protect the lives of workers and to ensure the health of workers, plant and mine extraction and health care arrangements (Articles 117 and 125 of the Charter) have been prioritized (no content) [6]. On December 10, 1918, the Labor Code (hereinafter, the Labor Code of 1918), which contained the basic provisions of the 
former Soviet Union government decrees (in no event was the Government's decree) in the sphere of labor regulation of labor and workers.

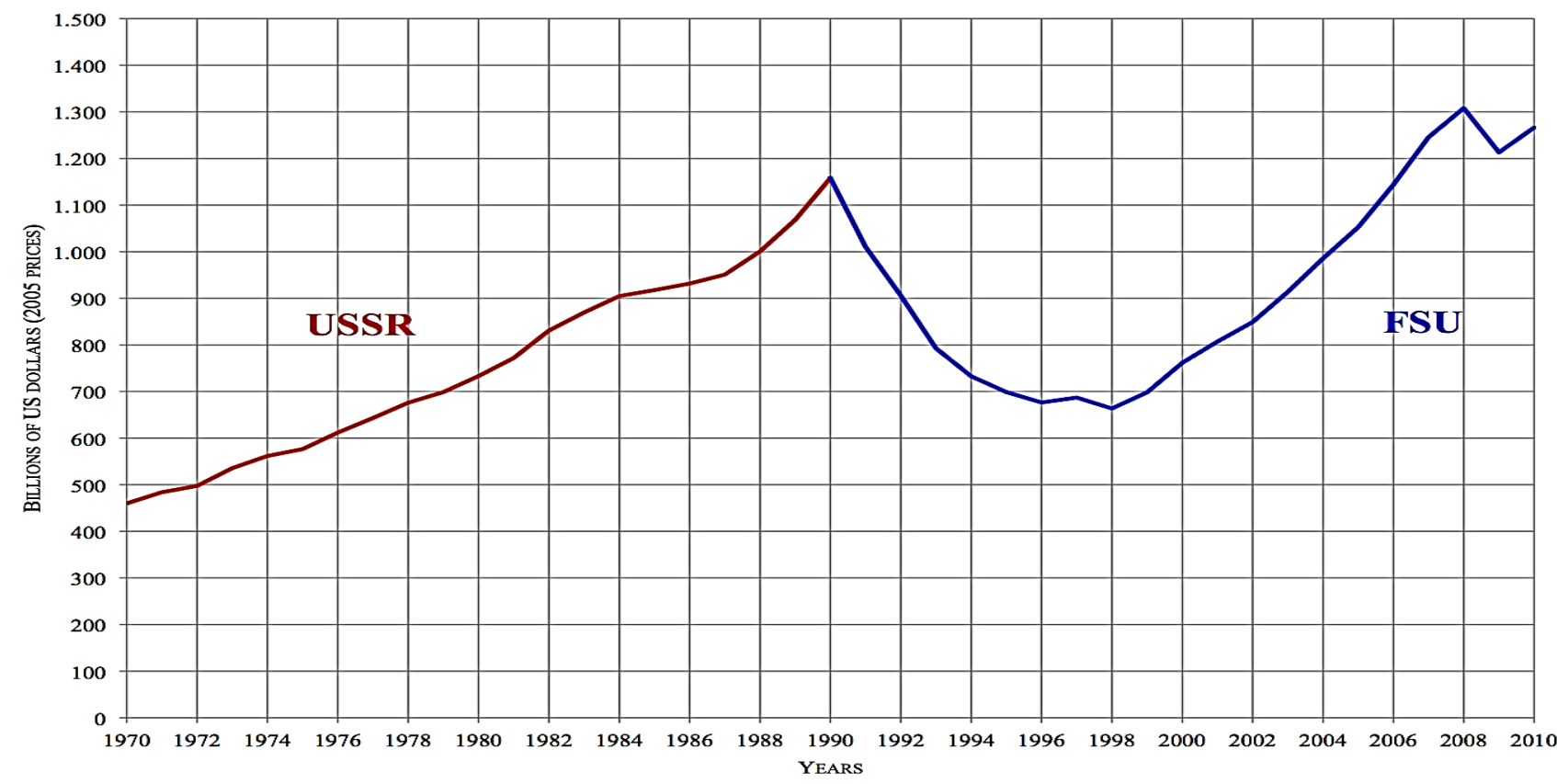

Figure 3. Accident rate in the Russian Federation industry, 1970-2010. Source: https://www.google.com/imgres?imgurl=https\%3A\%2F\%2Fi.imgur.com\%2FJiZapP.jpg.

It is clear from this picture that since 1970, the level of accidents in the USSR has slowly grown. Despite the stabilization of the situation in 1998, industrial accidents in 2010 amounted to 1.200.000 workers. As a result of the high level of human safety accident rate in the country happened in 2008 by 1.300 .000 workers.

\section{United States}

At the end of the XIX century, he was the first to investigate workplace safety in the United States. At the time of country's industrialization, workers were worried about working in animals, hand tools, stairs and elevations. Later, steam engines and heavy machinery posed new threats to the safety of workers. However, in the workplace, these new technologies have led to a high level of human life-style accidents. However, new approaches to industrial revolution have been highly dangerous in the US than in other countries. Research from 1900 shows that more than half of the injured were half of the average paid damages. Since the effects of accidents are very low, production methods have little relevance to their safety. The most dangerous working conditions in the United States were observed in its mining industry. In the 19th century, the American Railroad Service served not only its employees but also its passengers at a higher risk level (https://clck.ru/FbvzW).

Due to not industrial development and some sectors which related with high risks US oil, mining and heavy manufacturing sector developed rapidly (https://clck.ru/Fbvzk). By 1910, the US Congress established the Mining Authority Bureau for many accidents and rising catastrophes. It was the first organization in the US to regulate the lives of its first employees. Reforms in this area have benefited greatly for the allies. The head of the US Federal Labor Commission, Samuel Gompers, examined the system of compensation for workers in hard working conditions in Germany. He said he was interested in encouraging entrepreneurs to work with safe working conditions and forty-four state compensation laws were adopted between 1911 and 1921. 
Table 2 .

ACCIDENT RATE OF INDUSTRIAL PRODUCTION AND MINING INDUSTRY THE THEIN US, 1926-1970 (million manpower) [6]

\begin{tabular}{ccc}
\hline \multirow{2}{*}{ Year } & \multicolumn{3}{c}{ Company } \\
\cline { 2 - 3 } & Industry & Mining \\
\hline 1926 & 24.2 & 93.2 \\
1931 & 18.9 & 89.9 \\
1939 & 14.9 & 69.5 \\
1945 & 18.6 & 60.7 \\
1950 & 14.7 & 53.3 \\
1960 & 12.0 & 43.4 \\
1970 & 15.2 & 42.6 \\
\hline
\end{tabular}

In the 1960s, political upheaval began to be triggered by the sharp increase in the level of injury caused by economic growth in the country. On December 29, 1970, President Richard Nixon and the US Congress established the Occupational Safety and Health Administration (OSHA) and the Occupational Safety and Health Office.

During the First and Second World War, big companies were concerned about human health and life-saving. After 1910 the mortality rates of the railroad workers have been steadily declining and labor safety has improved dramatically in a number of large enterprises, such as DuPont and in all sectors such as steel production.

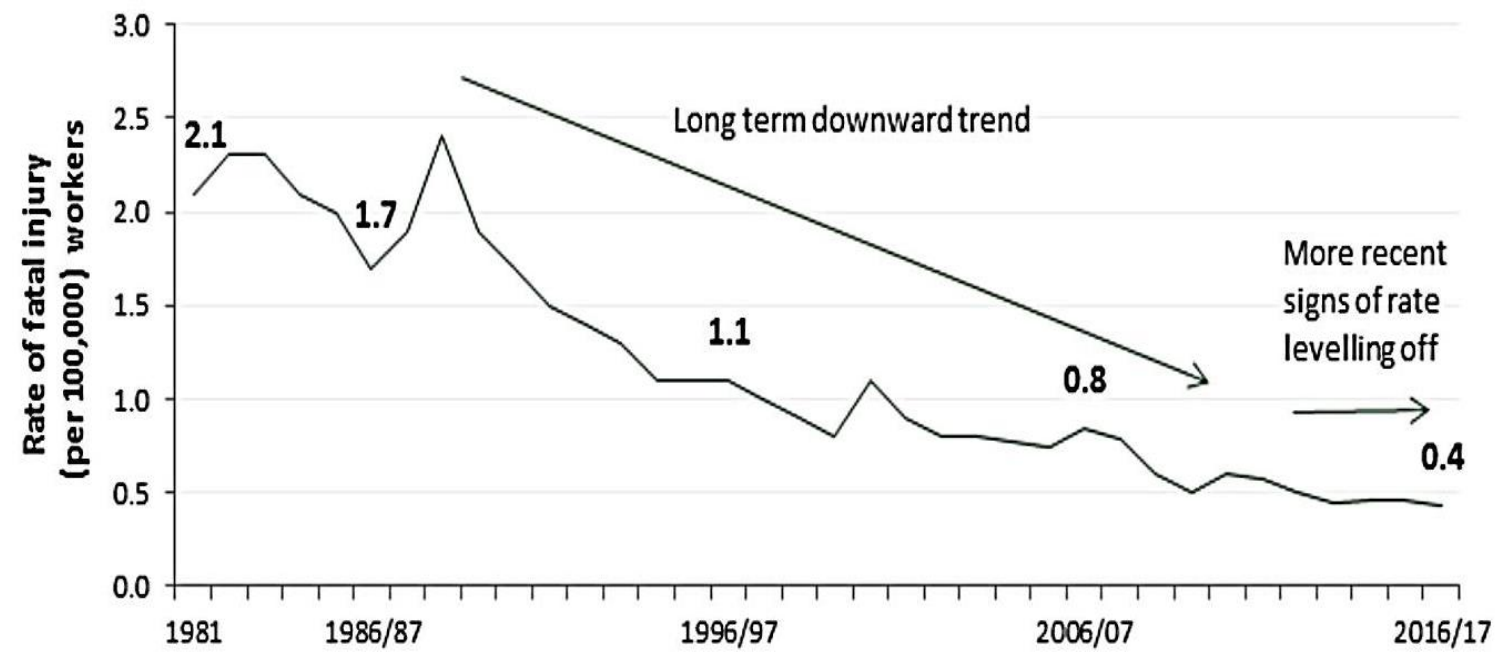

Figure 4. Accident rate in US industry, 1981-2017 [6].

The manner in which these institutions work has resulted in many controversy, but after a year of effective reform, they have been experiencing a continual downturn in work injuries. 
Table 3 .

LIST OF LEGISLATION AND REGULATION REFORMS THEIN USA (https://clck.ru/Fbw2D)

\begin{tabular}{lc}
\hline \multicolumn{1}{c}{ Name of legislation } & Year \\
\hline The first policy on accidents in North America was issued. & 1812 \\
Industrial nurses were registered in Boston. & 1913 \\
The US Supreme Court upheld the constitutionality of state employee's compensation laws. & 1916 \\
The first Industrial Safety Course was organized at Boston College of Business Administration & 1917 \\
College (MBA). & 1935 \\
The Law on Social Protection for State Industrial Programs has been adopted. & 1936 \\
Walsh-Healey Act has entered into force for occupational health and safety standards, & 1948 \\
The law on paying compensation to workers in all states (48 at that time) under severe labor & \\
conditions & 1959 \\
The Insurance Institute for Road Safety has been established. & 1970 \\
Occupational health and safety laws by President Richard Nixon &
\end{tabular}

The main purpose of this law was to create working environments in which workers were free from risks such as toxic chemical exposure, excessive noise levels, mechanical hazards, heat or cold stress, and unfavorable working conditions. According to the US Occupational Safety and Health Administration, over the past two years, 14,000 workers have died in the workplace, and 2 million have been disabled or seriously injured (https://clck.ru/Fbw2N).

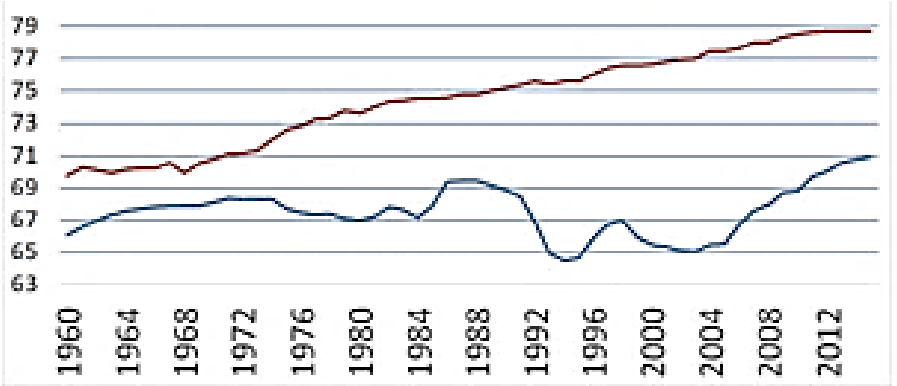

Figure 4. Life expectancy in Russia and the US, 1960-2015 (https://clck.ru/Fbvz5).

More than 8 million jobs in the United States are \$ 130 million. there are approximately 2100 security inspectors responsible for the health and safety of the worker. In the private sector, 4,674 workers in 2017 have been trapped in the construction sector, with overdue death to 971 workers or $20.7 \%$ of accidents. The warning slogan, known as the Dangerous Quadrant, was introduced in construction industry workers, with the exception of a collision, and more than half $(59.9 \%)$ of the construction workers were brought to trial in 2017. The sharp drop in the dangerous quarters is reflected in every year in the United States, the saving lives of 582 workers. The goals of human health and safety programs are to create safe and healthy working conditions. In this context, the implementation of the International Labor Organization's "Specific risk protection" program in our country plays an important role in ensuring the safety of the workers the of construction industry [7].

According to this organization, about 270 million accidents occur every year in the world. With direct labor activity up to $\$ 2$ million. employees die from premature death. Also 160 million dollars. occupational diseases have been associated with occupational diseases. In the CIS, the number of occupational diseases is more than 11 thousand cases. Human health and safety cases have resulted in deaths of 651,279 employees a year. According to ILO statistics global losses have 
led to the loss of around 4\% (\$1.25 trillion) of global GDP per year. Including $337 \mathrm{mln}$. The total loss amounted to 890 million dollars. US dollars.

At the moment economic integration of Uzbekistan into the world community is intensifying, the health and safety of workers in the construction industry in accordance with international standards and standards is the basis of the President of our country Sh. M. Mirziyoev is one of the most important tasks in realizing the full implementation of his interpretations of "human interests above everything" (http://uza.uz/oz/documents). Accordingly, reforming the construction industry in the above-mentioned direction on the basis of the "introduction of modern international construction standards" in accordance with the Concept the of development strategy of our country up to 2035 plays a crucial role in achieving the set objectives [6]. Particularly in the Annex 2 of the Decree of the President of the Republic of Uzbekistan "On measures to improve the rating in the Annual Report of the World Bank and International Finance Corporation" of February 5, 2019, further improve the quality of control quality in construction the specific priorities for 2019-2022 will be justified by the fact that this issue is of great importance today [2].

\section{Conclusion}

In conclusion, it should be noted that any business engaged in labor activity will, of course, be exposed to any kind of risk or accidents. Some of these risks, along with the consequences the of high risk of injury, are of great importance for people to get out of the way. After all, it is possible to drastically reduce or eliminate accidents by putting into practice the scientifically-developed solutions of these unpleasant situations. It is getting to difficult that US, UK or the FSU the was leader of that time in this occasion. Because in the US it is clear that oil and mining industry a was priority in the beginning. And in the UK we can see first safety regulations requested the in cotton industry sector but in FSU also heavy industry and machinery activities required safety regulations. It means in the early stages of 20 century's these three countries already generated fundamentals and principles of the health and safety legislation to protect workers and business.

We have the potential for sustainable development of socio-economic relationships of our workers by providing health protection and security to our country's construction industry [7]. In spite of development of the reforms in economic and public relations there few directions at technical science should be created as a single work effective mechanism in construction industry in Uzbekistan. Modern city building and urban planning state projects are only beginning of the transformation of ancient Uzbek cities cross line via Great Silk road with western style architecture. Western world experiences imply that construction workers are six times more likely to be killed at work than other workers for. As rest countries of the world Uzbekistan is also continuously upgrading legislation safety regulation in the country.

\section{References:}

1. Rodden, J. (2011). The long shadow of the Industrial Revolution: Political geography and the representation of the left. Historical, political and economic development in Western Europe: Recent advances in comparative politics. Madrid.

2. Industrial Development Report (2018). Demand for Manufacturing: Driving Inclusive and Sustainable Industrial Development, UNIDO, 157. https://clck.ru/Fbvyy

3. Health and Safety at work Summary statistics for Great Britain (2018). p1. https://clck.ru/FbvzS.

4. Balabanova, D., McKee, M., Pomerleau, J., Rose, R., \& Haerpfer, C. (2004). Health service utilization in the former Soviet Union: evidence from eight countries. Health services research, 39(6p2), 1927-1950. 
5. Lawrie, G. A., \& Samoylova, O. (2010, January). Health, Safety \& Environment in the Russian Oilfield. In: SPE International Conference on Health, Safety and Environment in Oil and Gas Exploration and Production. Society of Petroleum Engineers.

6. Institute of Medicine (US) Committee to Assess Training Needs for Occupational Safety and Health Personnel in the United States. Safe Work in the 21st Century: Education and Training Needs for the Next Decade's Occupational Safety and Health Personnel. Washington (DC): National Academies Press (US); 2000. C, Significant Events in the History of Occupational Safety and Health. Available from: https://www.ncbi.nlm.nih.gov/books/NBK225533/

7. United States. (1975). Bureau of the Census. Historical statistics of the United States, colonial times to 1970. US Department of Commerce, Bureau of the Census, (93).

\section{Список литературы:}

1. Rodden J. The long shadow of the Industrial Revolution: Political geography and the representation of the left//Historical, political and economic development in Western Europe: Recent advances in comparative politics. Madrid. 2011.

2. Industrial Development Report Demand for Manufacturing: Driving Inclusive and Sustainable Industrial Development, UNIDO, 2018. 157. https://clck.ru/Fbvyy

3. Health and Safety at work Summary statistics for Great Britain. 2018. P. 1. https://clck.ru/FbvzS.

4. Balabanova D. et al. Health service utilization in the former Soviet Union: evidence from eight countries // Health services research. 2004. V. 39. №6p2. P. 1927-1950.

5. Lawrie G. A. et al. Health, Safety \& Environment in the Russian Oilfield // SPE International Conference on Health, Safety and Environment in Oil and Gas Exploration and Production. Society of Petroleum Engineers, 2010.

6. Institute of Medicine (US) Committee to Assess Training Needs for Occupational Safety and Health Personnel in the United States. Safe Work in the 21st Century: Education and Training Needs for the Next Decade's Occupational Safety and Health Personnel. Washington (DC): National Academies Press (US); 2000. C, Significant Events in the History of Occupational Safety and Health. Available from: https://www.ncbi.nlm.nih.gov/books/NBK225533/

7. United States. Bureau of the Census. (1975). Historical statistics of the United States, colonial times to 1970 (No. 93). US Department of Commerce, Bureau of the Census.

Работа поступила

в редакичию 10.03.2019 г.
Принята к публикациии 15.03.2019 2.

Cite as (APA):

Zikriyoev, A. (2019). Revitalizing Early Stages of Health and Safety Legislation as a Challenge Among Major Economies. Bulletin of Science and Practice, 5(4), 359-367. https://doi.org/10.33619/2414-2948/41/51.

Ссылка для ичитирования:

Zikriyoev A. Revitalizing Early Stages of Health and Safety Legislation as a Challenge Among Major Economies // Бюллетень науки и практики. 2019. Т. 5. №4. С. 359-367. https://doi.org/10.33619/2414-2948/41/51. 